\title{
Identifikasi dan Distribusi Gulma di Lahan Pasir Pantai Samas, Kabupaten Bantul, Daerah Istimewa Yogyakarta
}

\author{
DOI 10.18196/pt.2014.028.90-98
}

\author{
Junaidi Ilham \\ PT. Tiga Pilar Sejahtera Agro, Gd. Plaza Mutiara Lt. 16 Suite 1601, Jl. Dr. Ide Anak Agung Gde Agung Kav. E.1.2 No. 1 Ė2 Kawasan Mega \\ Kuningan, Kel. Kuningan Timur, Kec. Setiabudi, Jakarta Selatan - 12950, Indonesia, Telp (021) 57956768, Fax (021) 57853456, \\ email: j.ilham@tigapilar.com
}

\begin{abstract}
ABSTRAK
Penelitian tentang Identifikasi Dan Distribusi Gulma Di Lahan Pasir Pantai Samas, Kabupaten Bantul, DIY dilaksanakan bertujuan untuk mendapatkan jenis-jenis dan distribusi gulma di daerah lahan pasir pantai Samas, dengan diketahuinya jenis-jenis dan karakteristik gulma yang ada di lahan pasir pantai Samas dapat mempermudah dalam pengendalian gulma. Penelitian dilakukan dengan metode survei yang teknik pelaksanaannya menggunakan analisis vegetasi dan wawancara. Analisis vegetasi untuk menentukan, jenis tanaman dominan, menentukan petak sampel pengamatan dan selanjutnya dilakukan identifikasi gulma, variabel yang diamati dalam identifikasi gulma yaitu kerapatan gulma, frekwensi gulma, dominansi gulma, nilai komunitas (C) dan SDR (Summed Dominanc Ratio). Data dari hasil analisis vegetasi yang berupa data kuantitatif selanjutnya dianalisis menggunakan sidik ragam. Wawancara dilakukan untuk mendapatkan informasi terkait pengendalian gulma yang selama 'ini dilakukan oleh petani di lahan pasir pantai Samas. Hasil penelitian menunjukan bahwa secara umum gulma dominan pada tiap tanaman Cabai, terong, jagung, kacang tanah dan gulma dominan hidup di laban pasir pantai Samas merupakan gulma berdaun sempit termasuk gulma golongan C4, yaitu Eleusine indica L, Cyperus rotundus, Cyperus iria dan Digitaria ciliaris efektif dikendalikan dengan cara preventif, kultur teknis, mekanis dan biologis.

Kata kunci: Lahan pasir pantai, Gulma dominan, Pengendalian gulma
\end{abstract}

\begin{abstract}
A research on identification and distribution of weed on samas coastal, Bantul, DIY aims to get the types and distribution of weeds in the area of Samas sandy coastal, in recognition of the types and characteristics of weeds in fields Samas beach sand to ease in weed control. The research was conducted by survey method that the implementation techniques used the analysis of vegetation and interviews. Vegetation analysis to determine the dominant plant species, determine sample plots observation and further to identify weeds, observed variables in the identification of weeds is weed density, frequency of weeds, weed dominance, coefficient of community (C) and SDR (summed Dominance Ratio). Data from the analytic vegetation result in the form of quantitative data were further analyzed using analysis of variance. Interviews were conducted to obtain information about weed control that usually done by farmers in Samas beach sand land. The results of research showed that weeds dominant in each plant peppers, eggplant, corn and peanuts and dominant weeds on Samas sandy coastal is narrow- leaved weeds, including weeds class C4, that is Eleusine indica L, Cyperus rotundus, Digitaria ciliaris and Cyperus iria effectively controlled by means of preventive, technical culture, mechanical and biological. Keywords: Sandy coastal, Dominant weeds, Weed control
\end{abstract}

\section{PENDAHULUAN}

Lahan pasir pantai merupakan lahan marjinal yang memiliki produktivitas rendah. Produktivitas lahan pasir pantai yang rendah disebabkan oleh faktor pembatas yang berupa kemampuan memegang/menyimpan air rendah, infiltrasi tinggi, bahan organik sangat rendah dan efisiensi penggunaan air rendah (Kertonegoro, 2001). Lahan pasir pantai ini dapat dimanfaatkan untuk mengembangkan sektor pertanian. Salah satu lahan pasir pantai yang sudah dikembangkan untuk budidaya pertanian yaitu lahan

pasir pantai Samas. Pantai Samas merupakan lahan pasir yang dimanfaatkan untuk budidaya berbagai jenis tanaman pertanian, seperti cabai, kacang tanah, bawang merah, buah naga dan lain-lain. Dalam budidaya tanaman, petani sering mengalami mengalami berbagai macam permasalahan, dan salah satunya adalah gulma.

Gulma maupun tanaman budidaya mempunyai keperluan dasar yang sarna untuk pertumbuhan dan perkembangannya yaitu unsur hara, air, cahaya dan ruang temp at tumbuh. Gulma 
harus dikendalikan karena sangat merugikan bagi tanaman yang .akan dibudidayakan, karena gulma dapat menurunkan hasil dan produktifitas tanaman budidaya, disamping itu gulma dapat mengeluarkan zat allelopati yang mengakibatkan sakit atau matinya tanaman utama. Besamya kerugian yang ditimbulkan gulma mengharuskan petani melakukan pengendalian. Saat ini petani melakukan pengendalian gulma menggunakan pestisida yang sangat berlebihan. Padahal pengendalian gulma harus mengetahui karakteristik gulma dengan eara identifikasi gulma, sehingga hasil yang diperoleh lebih optimal.

Oleh karena itu perlu dilakukan penelitian tentang analisis vegetasi gulma pada lahan pasir pantai. Penelitian ini bertujuan untuk mengetahui jenis-jenis dan distribusi gulma didaerah lahan pasir pantai Samas, dengan diketahuinya jenis-jenis dan karakteristik gulma yang ada dilahan pasir pantai Samas dapat mempermudah dalam pengendalian gulma.

\section{BAHAN DAN METODE}

Penelitian dilaksanakan di Lahan Pasir Pantai Samas, Kabupaten Bantul, Daerah Istimewa Yogyakarta. Metode penelitian yang digunakan yaitu metode survei dengan teknik pelaksanaannya melalui analisis vegetasi dan wawancara.

Analisis vegetasi dilakukan dengan metode kuadrat untuk mendapatkan komposisi jenis dan struktur vegetasi. Luasan lahan yang dipilih sebanyak $10 \%$ atau seluas 7 ha dan dibagi menjadi 5 blok yang mewakili berbagai kondisi lahan. Pengambilan sampel pengamatan pada masing-masing blok berdasarkan jumlah petakan lahan budidaya, umur tanaman dan jenis-jenis tanamanan di setiap petakan, petakan yang digunakan seluas $0,5 \times 0,5 \mathrm{~m}$. Parameter yang diamati yaitu: kerapatan gulma, frekuensi gulma, dominansi gulma, SDR (Summed Dominance Ratio) dan nilai koefisien komunitas (C) (Tjitrosoedirdjo et al., 1984).

Wawancara dilakukan untuk melengkapi data yang diperoleh melalui analisis vegetasi. Teknik pengambilan sampel dilakukan dengan probability sampling. Jumlah populasi petani lahan pasir di Samas sebanyak 170 orang, total responden yang digunakan dalam penelitian ini $10 \%$ dari total populasi atau sebanyak 17 orang. Pertanyaan yang akan diberikan kepada responden yaitu pertanyaan yang berhubungan permasalahan gulma di laban pasir pantai dan cara pengendaliannya.

\section{HASIL DAN PEMBAHASAN}

Jenis Gulma Dominan

Secara umum, gulma dominan pada tanaman budidaya di lahan pasir merupakan jenis gulma berdaun sempit dan tergolong tanaman C4 (Tabel 1). Gulma berdaun sempit bereproduksi secara vegetatif dengan stolon maupun secara generatif dengan biji yang mampu bertahan didalam tanah sehingga dapat tumbuh jika kondisi memungkinkan untuk tumbuh. Gulma golongan $\mathrm{C} 4$ lebih efisien menggunakan air, suhu dan toleran terhadap lingkungannya sehingga gulma Ca lebih kuat bersaing untuk tumbuh. Hal ini disebabkan gulma golongan $\mathrm{C} 4$ memiliki sel seludang berkas yang tertata dengan baik dan kaya organel. Gulma golongan $\mathrm{C} 4$ tumbuh dominan pada kondisi tanah lembab/ kering (Syakir M, 2008). Gulma berdaun sempit bereproduksi secara vegetatif dengan stolon maupun secara generatif dengan biji yang mampu bertahan didalam tanah dan akan tumbuh kembali jika kondisi lingkungan memungkinkan untuk tumbuh.

Gulma dominan pada tanaman cabai monokultur, tumpangsari cabai dan kacang tanah, 
tumpangsari jagung dan cabai, tumpangsari jagung dan kacang tanah serta monokultur kacang tanah menunjukan jenis gulma yang paling banyak (Tabel 1). Hal ini disebabkan naungan pada tanaman budidaya pada tipe tanaman diatas tidak mampu menahan sinar matahari. Sinar matahari yang tak terhalang sangat mempengaruhi pertumbuhan gulma, cahaya sinar matahari sumber energi utama untuk berlangsungnya proses fotosintesis.

Tabel 1. Nilai SDR (Summed Dominance Ratio) Jenis Gulma Dominan

\begin{tabular}{|c|c|c|c|c|c|}
\hline Jenis Tanaman & Jenis Gulma & $\begin{array}{l}\mathrm{KN} \\
(\%)\end{array}$ & $\begin{array}{l}\text { DN } \\
(\%) \\
\end{array}$ & $\begin{array}{l}\mathrm{FN} \\
(\%)\end{array}$ & $\begin{array}{l}\text { SDR } \\
(\%)\end{array}$ \\
\hline \multicolumn{6}{|l|}{ Cabai } \\
\hline \multirow[t]{3}{*}{ Cabai } & E. indica $L$ & 8,92 & 39,02 & 13,2 & 20,36 \\
\hline & D. ciliaris & 18,81 & 14,23 & 15,8 & 16,28 \\
\hline & C. rotundus & 24,75 & $11 ; 65$ & $10 ; 5$ & $15 ; 64$ \\
\hline \multirow[t]{2}{*}{ Cabai + Kacang Tanah } & E. indica $L$ & 20 & 61,39 & 30 & 37,13 \\
\hline & C. rotundus & 46 & 14,41 & 25 & 28,47 \\
\hline Cabai + Terong & C. rotundus & 50 & 73,8 & 33,34 & 52,37 \\
\hline Cabai + Ketela Rambat & E. indica $L$ & 50 & 86,45 & 50 & 62,15 \\
\hline \multicolumn{6}{|l|}{ Terong } \\
\hline Terong & C. rotundus & 63,64 & 39,41 & 28,58 & 43,87 \\
\hline Terong + Cabai & D. ciliaris & 20 & 58,11 & 20 & 32,7 \\
\hline Terong + Kacang Tanah & C. rotundus & 87,5 & 65,7 & 50 & 67,74 \\
\hline Terong + Cabai + Kangkung & E. indica $L$ & 75 & 92,01 & 50 & 72,34 \\
\hline \multicolumn{6}{|l|}{ Jagung } \\
\hline \multirow[t]{2}{*}{ Jagung + Cabai } & C. iria & 36,48 & 26,87 & 20 & 27,78 \\
\hline & E. Indica $L$ & 27,42 & 25,95 & 20 & 24,46 \\
\hline \multirow[t]{2}{*}{ Jagung + Kacang Tanah } & C. rotundus & 20,35 & 37,35 & 20 & 29,23 \\
\hline & E. indica $L$ & 21,82 & 24,87 & 20 & 22,23 \\
\hline \multicolumn{6}{|l|}{ Kacang Tanah } \\
\hline Kacang tanah & C. iria & 14,37 & 39,15 & 28,44 & 27,32 \\
\hline C. rotundus & C. rotundus & 31,7 & 21,18 & 14,43 & 24,44 \\
\hline
\end{tabular}

Keterangan: $\mathrm{KN}=$ Kerapatan Nisbi, DN=Dominasi Nisbi, FN=Frekuensi Nisbi, $S D R=$ Summed Dominance Ratio

Gulma dominan pada tanaman Cabai tumpangsari serta terong baik monokultur maupun tumpang sari menunjukan jumlah jenis gulma yang lebih sedikit (Tabel 1). Hal ini disebabkan permukaan tanah tertutup oleh tajuk tanaman yang mengakibatkan terhambatnya sinar ma- tahari untuk berlangsungnya proses fotosintesis gulma, sehingga menghambat pertumbuhan gulma. Kanopi yang rimbun dapat menekan pertumbuhan gulma yang berada dibawah naunganya.

Gulma dominan pada tanaman tanaman kacang tanah merupakan gulma Teki. Hal ini disehahkan tanaman kacang tanah tumhuh secara perdu, sehingga tanah tertutup dan menurunkan intensitas sinar matahari menjadikan kondisi tanah menjadi lemhah. Kondisi tanah yang lembab sesuai dengan karakter hidup gulma Teki. Tanaman kacang tanah merupakan spesies kacang-kacangan dari famili Leguminoceae memiliki bakteri Rhizobium yang dapat menghambat nitrogen di udara untuk menyuburkan tanah, kandungan tanah yang memiliki nitrogen telah hanyak diketahui perannya dalam meningkatkan perkecambahan tunas Rizoma pada gulma teki. Hal ini sesuai dengan pendapat Sastroutomo (1990), bahwa kandungan nitrogen pada Rizoma erat kaitannya dengan kandungan nitrogen dalam tanah dan Rizoma yang memiliki kandungan nitrogen tinggi lebih banyak menghasilkan tunas dari pada yang kandungan nitrogennya rendah.

Meskipun dari hasil analisis vegetasi gulma, jenis gulma dominan setiap tanaman budidaya baik secara monokultur maupun tumpangsari tidak berbeda namun ternyata mempunyai komunitas gulma yang (Heterogen) dengan nilai koefisien komunitas c $<75 \%$. (Tabel 2). Adanya perbedaan komunitas gulma yang mendominasi antar tanaman, hal ini berhubungan dengan kemampuan adaptasi gulma tersebut pada habitat yang ditempatinya, ada gulma yang mampu tumbuh pada area yang ternaungi dan ada juga gulma yang tahan terhadap suhu tinggi. Spesies gulma juga memiliki kemampuan yang berbeda untuk menanggapi ketersediaan faktor pertum- 
buhan seperti air, unsur hara dan cahaya yang jumlahnya terbatas. Gulma-gulma akan tumbuh dengan subur dan berkembang dengan baik pada tanah dengan kelembaban tinggi dan cahaya matahari yang cukup. Menurut Moenandir (1993), dalam lahan yang cukup subur, pertumbuhan gulma diantara tanaman budidaya menjadi lebih banyak daripada di lahan yang kurang subur.

Tabel 2. Nilai Koefisien Komunitas (C) (\%)

\begin{tabular}{lc}
\hline \multicolumn{1}{c}{ Perbandingan Antar Tanaman } & Koefisien Komunitas (\%) \\
\hline Cabai & 52,28 \\
Cabai : Cabai + Terong & 39,78 \\
Cabai : Cabai + Kacan tanah & 33,01 \\
Cabai : Cabai + Ketela rambat & \\
Terong & 64,31 \\
Terong : Cabai & 43,35 \\
Terong : Kacang tanah & 45,65 \\
Terong : Cabai + Kangkung & \\
Jagung & 52,4 \\
Jagung + Kacang tanah & 43,5 \\
Jagung + Cabai &
\end{tabular}

Keterangan: Nilai koefisien komunitas C > 75\% komunitas gulma Homogen, jika nilai koefisien komunitas $\mathrm{C}<75 \%$ komunitas gulma Heterogen

\section{Gulma Dominan di Lahan Pasir Pantai danCara} Pengendaliannya

Hasil analisis vegetasi gulma, menunjukan bahwa jenis gulma yang dominan di lahan pasir pantai Samas yaitu Eleusine indica L (20,15\%), Cyperus rotundus (19,01\%), Cyperus iria (11,91\%) dan Digitaria ciliaris (11,60\%) (Tabel 3).

Eleusine indica L termasuk kedalam gulma berdaun sempit, mempunyai batang yang selalu berbentuk cekungan, menempel pipih, pelepah menempel kuat, lidah daun pendek seperti selaput dan tumbuh dalam rumpun, dan batangnya seringkali bercabang. Daun Eleusine indica L terdiri dari dua baris, kasar pada tiap ujungnya, pangkal helai daun berambut, bulir bunga menjari 3-5, berkumpul pada sisi poros yang bersayap juga bertunas dan akar Eleusine indtca ini sangat kuat, batang selalu berbentuk cekungan, tinggi dapat mencapai $95 \mathrm{~cm}$. Gulma Eleusine indica L umumnya hidup pada tempat yang kering dengan intensitas penyinaran sepanjang hari, tumbuh pada ketingian 1- 2000 m dpl (Moenandir, 1993). Pengendalian Eleusine indica L yang efektif dan efisien dapat dikendalikan dengan cara preventif, mekanis dan kultur teknis.

Tabel 3. Nilai SDR (Summed Dominance Ratio) Gulma di Lahan Pasir Pantai

\begin{tabular}{|c|c|c|c|c|c|}
\hline No. & Jenis Gulma & KN (\%) & DN (\%) & FN (\%) & SDR $(\%)$ \\
\hline 1. & Eleusine indica L & 10,62 & 35,16 & 14,68 & 20,15 \\
\hline 2. & Cyperus rotundus & 31,16 & 12,10 & 13,76 & 19,01 \\
\hline 3. & Cyperus iria & 17,12 & 10,36 & 8,26 & 11,91 \\
\hline 4. & Digitaria ciliaris & 11,99 & 11,79 & 11,01 & 11,60 \\
\hline 5. & Pyllanthus amarus & 7,53 & 6,16 & 9,17 & 7,62 \\
\hline 6. & Oxonopus compressus & 3,77 & 5,10 & 8,26 & 5,71 \\
\hline 7. & Dactyloctenium aegyptuium & 4,11 & 4,67 & 6,42 & 5,07 \\
\hline 8. & Amaranthus spinosus & 1,37 & 4,11 & 2,75 & 2,74 \\
\hline 9. & Heliotropium & 1,71 & 1,59 & 4,59 & 2,63 \\
\hline 10. & Euphorbia hirta & 2,05 & 0,50 & 4,59 & 2,38 \\
\hline 11. & Sclreia sp & 2,40 & 0,59 & 3,67 & 2,22 \\
\hline 12. & Portulaca oleracea & 1,37 & 1,15 & 3,67 & 2,06 \\
\hline 13. & Ottochloa nodusa & 1,03 & 3,19 & 1,83 & 2,02 \\
\hline 14. & Cleome rutidosperma & 2,05 & 0,34 & 2,75 & 1,72 \\
\hline 15. & Eclipta alba & 0,34 & 0,93 & 0,92 & 0,73 \\
\hline 16. & Digitaria loneitlora & 0,34 & 0,90 & 0,92 & 0,72 \\
\hline 17. & Echinochloa Crusgealli & 0.34 & 0.75 & 0.92 & 0,67 \\
\hline 18. & Cyrtococcum accrescens & 0,34 & 0,32 & 0,92 & 0,53 \\
\hline 19. & Eragrostis renela & 0,34 & 0,28 & 0,92 & 0,51 \\
\hline & Total & 100 & 100 & 100 & 100 \\
\hline
\end{tabular}

Keterangan: KN=Kerapatan Nisbi, DN=Dominasi Nisbi, FN=Frekuensi Nisbi, SDR = Summed Dominance Ratio

Cyperus rotundus merupakan gulma tahunan berkembang biak dengan biji dan umbi akar, tumbuh tegak, berbentuk segitiga, tingginya 10$50 \mathrm{~cm}$ dan penampangnya $1-2 \mathrm{~mm}$. Permukaan daun berwarna hijau tua dan permukaan daun bawah hijau muda, lebar daun 26 mm. Bunga C. rotundus memiliki bulir tunggal, berwama cokelat, satu bulir berbunga sepuluh sampai empat puluh. Sistem perakaran C. rotundus serabut dengan rambut-rambut halus, akar memiliki banyak anak cabang akar yang menyebar 
didalam tanah. Umbi C. rotundus memiliki mata tunas yang mampu menjadi individu baru, umbi pertama kali dibentuk pada tiga minggu setelah pertumbuhan awal. C. rotundus toleran terhadap genangan, mampu bertahan pada kondisi suhu sekitar $13-14^{\circ} \mathrm{C}$. C. rotundus dapat tumbuh pada ketinggian 1-1.500 m dpl (Moenandir, 1993). C. rotundus gulma tahunan bereproduksi secara vegetatif dengan stolon dan rhizome yang mampu bertahan didalam tanah dan akan tumbuh kembali jika kondisi memungkinkan untuk tumbuh. Pengendalian C. rotundus yang efektif dan efisien dapat dikendalikan dengan cara mekanis dan biologis.

Cyperus iria gulma tahunan bereproduksi secara vegetatif dengan stolon dan rhizome dipangkal batang maupun secara generatif dengan biji yang mampu menghasilkan ribuan biji dan tergolong dalam tanaman teki. C. iria memiliki tinggi hingga 5-90 cm tinggi, memiliki akar serabut dan berumbi, panjang akar10-70 cm. Batang C. iria berumbi dan bersudut tajam, tekstur daun kasar. C. iria dapat menghasilkan sekitar 3000-5000 biji, bunga muncul dalam waktu sekitar satu bulan. C. iria turnbuh pada ketinggian 0-1.500 m dpl, C. iria sering ditemukan pada tempat-tempat yang menerima curah hujan lebih dari $1000 \mathrm{~mm}$ pertahun. (Galinato, 1999). Pengendalian C. iria yang efektif dan efisien dapat dikendalikan dengan cara preventif, kultur teknis, mekanis dan biologis.

Digitaria ciliaris gulma semusim menghasilkan ribuan biji, selain itu juga biji-biji gulma $D$. ciliaris dapat bertahan lama didalam tanah (masa dormansi yang panjang). D. ciliaris hidup berumpun yang pada pangkalnya kerap kali dengan batang yang merayap, tinggi hingga $1-1.2 \mathrm{~m}$, ruas $3-4 \mathrm{~cm}$. Batang D. ciliaris berwarna hijau pipih yang besar semakin ke bawah berongga, helaian daun berbetuk garis, bertepi kasar, berwarna keunguan, anak bulir berseling kiri dan kanan dari poros, berdiri sendiri dan berpasangan tetapi dengan tangkai yang tidak sama panjang, rontok bersama-sama, panjang $2-4 \mathrm{~mm}$ (Hairullah, 2013). Pengendalian D. ciliaris yang efektif dan efisien dapat dikendalikan dengan cara preventif, mekanis dan kultur teknis.

Pengendalian gulma secara preventif merupakan mencegah terjadinya infeksi dari pada perawatan tanaman budidaya. Pencegahan masuknya biji gulma ke areal budidaya dapat dilakukan dengan menggunaan bahan tanam bersih akan biji gulma. Penggunaan pupuk kandang yang sudah matang karena dikawatirkan pupuk kandang tidak matang mengandung biji-biji gulma masih dorman. Pembersihan gulma pada sumber air karena pada saat penyiraman air irigasi dapat tercampur dengan biji gulma. Penecegahan masuknya biji gulma melalui perantara angin dan hewan sulit dilakukan karena biasanya biji gulma berukuran kecil dan mudah terbawa angin.

Pengendalian dengan cara mekanis yaitu mencabuti gulma diareal tanaman budidaya secara rutin dapat membunuh gulma dan menghambat pertumbuhan gulma. Pelaksanaan pencabutan gulma sebaiknya dilakukan pada saat sebelum pertumbuhan aktif gulma dan sebelum pembentukan biji. Penyiangan tidak dilakukan pada Gulma dewasa karena gulma memiliki akar sangat kuat dan panjang dapat mencapai $10 \mathrm{~cm}$, apa bila dilakukan pencabutan dapat membongkar akar tanaman budidaya dan menimbulkan kerusakan fisik. Pengendalian mekanis dapat juga dilakukan dengan pemulsaan. Pemulsaan bertujuan untuk mempengaruhi cahaya yang akan sampai ke permukaan tanah terhambat oleh mulsa sehingga menyebabkan bijibiji gulma tidak dapat berkecambah. Pengendalian mekanis dapat juga dilakukan dengan pengolahan 
tanah. Pengolahan tanah akan mengakibatkan umbi akar naik keatas permukaan tanah, umbi akar tidak tahan kering, selama 14 hari di bawah sinar matahari daya turnbuhnya akan hilang

Pengendalian gulma dengan cara kultur teknis merupakan cara pengendalian gulma dengan menggunakan praktek-praktek budidaya. Pengendalian kultur teknis dengan cara rotasi tanam bertujuan memanfaatkan tanah, air, sinar matahari dengan penggiliran tanaman maka permukaan tanah akan selalu tertutup oleh naungan tanaman sehingga gulma tertekan pertumbuhannya, hal ini dikarenakan gulma berdaun sempit hidup pada tempat yang kering dengan intensitas penyinaran sepanjang hari. Pengendalian kultur teknis dengan cara sistem tanam tumpangsari efektif untuk menekan pertumbuhan gulma, cara tanam tumpangsari dapat menekan ruang tumbuh gulma dan bijibiji gulma yang dorman tidak dapat tumbuh dikarenakan tidak terkena sinar matahari sehingga gagal untuk berkecambah.

Pengendalian gulma secara biologi pada gulma C. rotundus dengan memanfaatkan ekstrak daun ketapang yang dapat menghambat pertumbuhan gulma C. rotundus. Menurut hasil penelitian Riskitavani dan Purwani, (2013) Ketapang diketahui mengandung senyawa obat seperti mengandung senyawa alkoloid, flavonoid, tannin, terpenoid, resin dan saponin pada ekstrak daun ketapang mengakibatkan efek fitotoksisitas

Pengendalian gulma secara biologi dapat dilakukan dengan memanfaatkan ekstrak tanaman. Esktrak Daun ketapang misalnya dapat menghambat pertumbuhan gulma C. iria. Menurut hasil penelitian Riskitavani dan Purwani (2013), Ketapang diketahui mengandung senyawa obat seperti mengandung senyawa alkoloid, flavonoid, tannin, terpenoid, resin dan saponin pada ekstrak daun ketapang mengakibatkan efek fitotoksisitas, pertumbuhan gulma menjadi terhambat Mekanisme penghambatan pertumbuhan gulma meliputi serangkaian proses kompleks yang melalui beberapa aktivitas metabolisme yang meliputi pengaturan pertumbuhan melalui gangguan pada zat pengatur tumbuh, pengambilan hara, fotosintesis, respirasi, pembukaan stomata, sintesis protein, penimbunan karbon, dan sintesis pigmen.

\section{Pertumbuhan Gulma}

Hasil analisis menunjukkan bahwa jumlah jenis, jumlah individu dan bobot kering gulma pada pada tanaman cabai monokultur dan cabai tumpang sari berbeda nyata (Tabel 4). Hal ini dikarenakan bentuk tajuk yang lebih kecil menjadikan sinar matahari masih mampu menembus tajuk dan mengenai biji gulma yang ada pada tanah. Biji biji gulma semula dorman terkena air dan sinar matahari dapat mempercepat perkecambahan yang akan mendorong biji gulma untuk tumbuh dan berkembang. Menurut Suroto (1996) pada lahan pertanian terdapat biji gulma/m2 sebesar $34.000-75.000$ terkubur didalam tanah dan di atas permukaan tanah, apa bila kondisi lingkungan menguntungkan biji gulma ini akan berkecambah sehingga keragaman spesies gulma tinggi sehingga jumlah jenis, jumlah individu dan bobot kering pada tanaman Cabai monokultur lebih banyak dibanding tanaman Cabai tumpangsari lebih sedikit. Hal ini diduga kerapatan tanaman terong tumpangsari lebih besar, maka kemampuan tanaman untuk bersaing dengan gulma juga meningkat sehingga mengurangi jumlah jenis, jumlah individu dan bobot kering gulma dan menyebabkan pergeseran komposisi gulma. Hal ini sejalan dengan pemyataan Mercado (1979) 
yang menyatakan bahwa sistem tanam tumpangsari dapat mempengaruhi penurunan spesies gulma yang tumbuh sehingga kompetisi gulma pada tanaman dapat ditekan interaksi dalam kompetisi.

Tabel 4. Rerata Jumlah Jenis, Jumlah Individu dan Bobot Kering Gulma pada Tanaman Cabai

\begin{tabular}{lccc}
\hline Sistem Pertanaman & $\begin{array}{c}\text { Jumlah Jenis Gulma } \\
\text { (Jenis) }\end{array}$ & $\begin{array}{c}\text { Jumlah Individu } \\
\text { (Tanaman) }\end{array}$ & $\begin{array}{c}\text { Bobot Kering } \\
\text { (g) }\end{array}$ \\
\hline Cabai & $7,8 \mathrm{a}$ & $20 \mathrm{a}$ & $35,27 \mathrm{a}$ \\
Cabai + Kacang Tanah & $4,0 \mathrm{~b}$ & $9,6 \mathrm{~b}$ & $14,08 \mathrm{~b}$ \\
Cabai + Terong & $0.6 \mathrm{~b}$ & $0,8 \mathrm{~b}$ & $3,37 \mathrm{~b}$ \\
Cabai + Ketela Rambat & $0,4 \mathrm{~b}$ & $0,4 \mathrm{~b}$ & $4,55 \mathrm{~b}$ \\
\hline
\end{tabular}

Keterangan: Nilai rerata yang diikuti huruf yang sama dalam kolom yang sama tidak ada berbeda nyata menurut uji Duncan pada taraf $5 \%$.

Pada tanaman terong monokultur jumlah jenis gulma lebih banyak dibanding tanaman terong tumpangsari. Jumlah jenis gulma tergantung pada faktor ketersediaan pertumbuhan yang ditempatinya seperti air, unsur hara dan cahaya sebagai penentu pertumbuhan dan perkembangan gulma. Spesies gulma yang tumbuh pada tanaman terong monokultur memiliki kemampuan adaptasi pada area yang temaungi oleh tajuk tanaman terong. Jumlah jenis gulma pada tanaman terong tumpangsari sedikit, karena pada tanaman terong tumpangsari kerapatan tanaman dan tajuk tanaman lebih lebar sehingga akan menghambat cahaya yang diteruskan kepermukaan tanah.
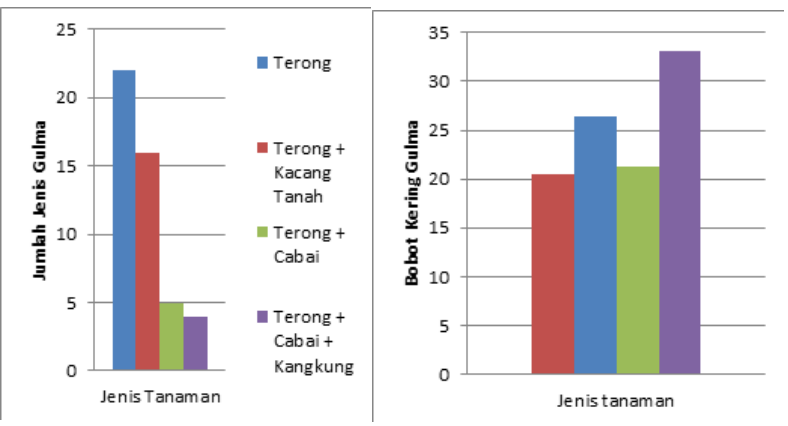

Gambar 1. Jumlah jenis gulma pada tanaman terong (kiri) bobot kering gulma pada tanaman terong (kanan)
Tanaman terong tumpangsari Cabai dan kangkung lebih tinggi bobot kering gulmnya. Hal ini diduga gulma mampu bersaing dengan baik dalam persaingan faktor pertumbuhan seperti air dan unsur hara yang tersedia mampu dimanfaatkan dengan baik oleh gulma sehingga bobot kering gulma pada tanaman terong tumpangsari Cabai dan kangkung lebih tinggi sedangkan bobot kering gulma pada tanaman terong tumpangsari sedikit. Oleh karena itu, semangkin tinggi bobot kering gulma berati menunjukkan bahwa semakin banyak unsur hara dan air yang diserap gulma.

\section{Pengelolaan Gulma Lahan Pasir Pantai Samas}

Jenis tanaman utama yang dibudidayakan petani lahan pasir pantai samas sebagian besar adalah cabai (36\%), terong (25\%), kacang tanah (12\%), jagung (12\%) dan melon. Pemilihan tanaman ini diadasari pada pengalaman dalam mengatasi kebutuhan tanaman pada musim kemarau. Sebagian besar tanaman utama tersebut dibudidayakan secara tumpangsari (75\%) dan sisanya menggunkan pola tanam monokultur. Penentuan tumpangsari sebagai praktek budidaya yang dilakukan oleh petani Samas bertujuan menghambat sinar matahari sampai ke permukaan tanah sehingga suhu tanah menjadi rendah, suhu tanah sangat mempengaruhi laju transpirasi, respirasi, penyerapan air dan fotosintesis apa bila peningkatan suhu tanah sampai titik optimum akan menurunkan aktivitas enzim. Pola tanaman tumpangsari juga dapat menekan pertumbuhan gulma. Hal ini disebabkan permukaan tanah tertutup oleh kerapatan tanaman dan tajuk tanaman yang mengakibatkan terhambatnya sinar matahari untuk berlangsungnya proses fotosintesis gulma, sehingga menghambat pertumbuhan. Tanaman yang dibudidayakan secara monokultur biasanya merupakan tana- 
man yang menjalar, tumbuh tinggi dan memiliki tajuk tanaman yang lebar, contoh tanaman yaitu kacang tanah, terong dan jagung.

Penyiapan lahan dilakukan dengan pencangkulan, pemupukan dan dilanjutkan dengan penanaman (76\%), 12\% petani lainnya menambahkan penyiraman sebelum penanaman dan 12\% lainnya melakukan pemupukan sebelum pengolahan tanah. Petani lahan Pantai Samas menambahkan pupuk kandang tanpa memperhatikan kematangan pupuk. Hal ini menyebabkan terjadinya penyebaran biji gulma melalui pemupukan. Irigasi yang dilakukan menggunakan system tadah hujan, dan bila dirasa diperlukan irigasi dilakukan dengan sumur bor/ mesin diesel (100\%). Hal ini disebabkan sumur bor lebih praktis dan untuk menyirami lahan pertanian pasir pantai Samas karena tinggal memompa air dari dalam tanah, irigasi sumur bor terhindar dari penyebaran biji-biji gulma. Sumber air sangat berpengaruh terhadap penyebaran gulma karena pada saat penyiraman dapat tercampur dengan biji gulma, sehingga penyebaran gulma lebih luas. Penyiraman lahan pasir pantai dilakukan dua kali sehari pada saat pagi hari dan sore hari pada jenis tanaman seperti Cabai, terong, jagung kacang tanah, dll. Tanaman disiram sampai tanaman benar-benar basah hal ini disebabkan kondisi lahan pasir pantai dan kemampuan memegang/menyimpan air tanah rendah.

Pengendalian gulma yang dilakukan petani samas $(73 \%)$ secara manual dengan mencabuti gulma diareal tanaman budidaya dan (27\%) pengendalian dengan cara penyemprotan herbisida. Pengendalian gulma yang dilakukan petani Samas dengan cara pencabutan/penyiangan sangat efektif dan ramah lingkungan. Pengendalian gulma secara manual atau mencabut gulma dengan tangan merupakan salah satu teknik yang sering diterapkan petani dalam budidaya tanaman. Mencabuti gulma secara rutin dapat menekan pertumbuhan gulma. Pada lahan=lahan yang tidak terlalu luas mencabut gulma dengan tangan memberikan hasil yang efektif dan efisien. Teknik pengendalian secara manual atau mencabut gulma dengan tangan mempunyai keunggulan yaitu hasilnya cepat terlihat, mudah untuk dilaksanakan, menghindarkan dampak polusi lingkungan dan pengendalian gulma secara manual juga mempunyai kelemahan yaitu membutuhkan tenaga kerja relative banyak, menyebabkan terjadnya erosi permukaan, pelukaan akar tanaman, tanah menjadi cekung sehingga tergenang air pada waktu hujan (dapat menyebabkan busuknya tanaman) dan rusaknya struktur tanah. Tingkat pengendalian gulma dengan menggunakan kimia/herbisida dapat dikatakan sangat rendah. Hal ini dapat disebabkan oleh faktor kesadaran petani akan dampak residu herbisida terhadap lingkungan. Sebagian petani menggunakan kimia/herbisida sebagai penggendalian gulma pada saat pra tanam, pada saat tanaman tumbuh besar petani tidak menggunakan kembali kimia/herbisida. Sebagian besar petani Samas yang menggunakan pola tanam tumpangsari mendapatkan keuntungan, dikarenakan tanaman tumpangsari dapat menekan pertumbuhan gulma.

Sebagian besar petani (87\%) melakukan penyiangan sebanyak >2 dalam satu musing tanam sedangkan sisanya melakukan penyiangan sebanyak satu kali. Petani yang melakukan penyiangan satu kali dalam satu musim tanam biasanya dilakukan saat masa generative tanaman. Petani yang melakukan $>2$ kali penyiangan dilakukan saat gulma telah mendominasi areal penanaman. Pengendalian gulma yang dilakukan petani Samas tidak memperhatikan jenis-jenis gulma, pertumbuhan aktif gulma dan gulma sudah 
menghasilkan ribuan biji yang tersebar terbawa angin, air dan hewan sehingga tingkat populasi gulma dilahan pasir pantai Samas tinggi mengharuskan penyiangan secara rutin.

Tingkat pengendalian gulma yang dilakukan petani Samas menggunakan herbisida dapat dikatakan sangat rendah hanya dilakukan satu kali penyemprotan herbisida. Hai ini dapat disebabkan oleh faktor kesadaran petani akan dampak residu herbisida terhadap lingkungan. Pengendalian gulma yang dilakukan petani Samas yaitu menggunakan herbisida pra tumbuh. Sebagian besar petani Samas menggunakan pola tanam tumpangsari yang secara otomatis dapat menekan pertumbuhan gulma.

\section{SIMPULAN}

Gulma dominan pada setiap tanaman budidaya di lahan pasir pantai Samas berbeda beda diantaranya adalah Eleusine indica L pada tanaman cabai dan kacang tanah, Cyperus rotundus pada tanaman terong, dan Cyperus iria pada tanaman jagung. Pengendalian gulma yang dilakukan oleh petani didominasi oleh kultur teknis, mekanis, dan kimiawi.

\section{DAFTAR PUSTAKA}

Galinato MI, Moody K, Piggin CM. 1999. Upland rice weeds of South and Southeast Asia. Manila (Philippines): International Rice Research Institute.

Mercado, B.L. 1979. Introduction to Weed Science. Southeast Asian Regional center for Graduate Study and Research in Agriculture (SEARCA), Laguna, Philippines. 292p.

Hairullah, Ahmad 2011. Biologi Penyakit Bercak Pada Gulma Digitaria ciliaris (Retz.) Koel. http://repository.unej.ac.id/ handle/123456789/2605. Diakses pada tanggal 7 Februari 2015.

Kertonegoro, B. D. 2001. Gumuk Pasir Pantai Di D.I. Yogyakarta :Potensi dan Pemanfaatannya untuk Pertanian Berkelanjutan. Prosiding Seminar NasionalPemanfaatanSumberdaya Lokal Untuk Pembangunan Pertanian Berkelanjutan. Universitas Wangsa Manggala pada tanggal 02 Oktober 2001.h46-54.

Moenandir, J. 1993. Ilmu Gulma Dalam sistem Pertanian Dalam Sistem Pertanian. Raja Grafindo Persada, Jakarta.
Riskitavani, Denada Visitia dan Kristanti Indah Purwani. 2013.http://ejumal.its.ac.id/index.php/sainsseni/article/ view/3593/1404. Diakses pada tanggal 9 february 2015

Sastroutomo, S. S. 1990. Ekologi Gulma. Gramedia Pustaka Utama, Jakarta

Suroto, D. 1996. Ilmu Gulma. Universitas Negeri Sebelas Maret. Surakarta. 103p.

Syakir, M, Bintoro, MH, Agusta, H \& Hermanto, 2008, Pemanfaatan Limbah Sagu Sebagai Pengendalian Gulma pada Lahan Perdu, Jurnal Littri 14 (3): 107-112

Tjitrosoedirdjo, S., H. Utomo, dan J. Wiroatmodjo., 1984. PengeloIaan Gulma di Perkebunan. PT Gramedia, Jakarta. 